\title{
Prevalence of Group A Rotavirus in Piglets in a Peri-Urban Setting of Arusha, Tanzania
}

\author{
Elizabeth Gachanja1, Joram Buza1, Pammla Petrucka2,3* \\ ${ }^{1}$ Nelson Mandela African Institution of Science and Technology, Arusha, Tanzania \\ ${ }^{2}$ College of Nursing, University of Saskatchewan, Regina, Canada \\ ${ }^{3}$ Adjunct Faculty, Nelson Mandela African Institute of Science and Technology, Arusha, Tanzania \\ Email: "pammla.petrucka@sasktel.net
}

Received 7 November 2015; accepted 4 January 2016; published 7 January 2016

Copyright (C) 2016 by authors and Scientific Research Publishing Inc.

This work is licensed under the Creative Commons Attribution International License (CC BY).

http://creativecommons.org/licenses/by/4.0/

(c) (i) Open Access

\begin{abstract}
Aims: Rotavirus-associated enteritis is a major problem in livestock, notably in young piglets and calves, and is also a zoonosis. It is also associated with diarrhoea mainly in children less than five years of age. In Tanzania however, no study has addressed Rotavirus in livestock species. Following our previous report on Rotavirus infection in children within urban and peri-urban Arusha, we sought to understand the disease situation in livestock in the same area. Study Design: Place and Duration of Study: In this study, we investigated the prevalence of Rotavirus in pigs of suckling, weaning and post weaning/grazing/fattening age categories in Lemara, Moshono and Sokoni I areas of Arusha peri-urban. Methodology: Molecular detection of Rotavirus in stool samples was done using conventional PCR with primers targeting Group A Rotavirus (GARV). Using a standardized questionnaire, we sought to find out risk factors associated with positive cases of Rotavirus including age, sex, location, diarrhoea status, recent diarrhoea case in the farm, breed, type of grazing system and type of feeding of individual pigs. Results: Out of a total of 110 pigs sampled (fecal samples), $41.8 \%$ were positive for Rotavirus. Chi Square's $\left(\chi^{2}\right)$ Fisher's Exact Test was used to relate PCR test results with various possible risk factors. Recent diarrhoea case in the farm was significantly $(p<0.05)$ associated with Rotavirus infection in pigs indicating the possible role of cross-infection within farm and also the environmental resistance and persistence of the virus in the farm. Conclusions: This was the first study to report on Rotavirus infection in pigs in Tanzania. The information obtained should form the platform for further studies to address the molecular epidemiology and relatedness of Rotavirus from human and porcine positive cases.
\end{abstract}

\section{Keywords}

Pigs/Swine, Group A Rotavirus, Diarrheal Prevalence, Tanzania

\footnotetext{
${ }^{*}$ Corresponding author.
}

How to cite this paper: Gachanja, E., Buza, J. and Petrucka, P. (2016) Prevalence of Group A Rotavirus in Piglets in a Peri-Urban Setting of Arusha, Tanzania. Journal of Biosciences and Medicines, 4, 37-44. 


\section{Introduction}

Viral diseases in swine cause a challenge to the swine industry by increasing cost of treatment and prevention and potentiating loss of stock quality through disease and/or death. These losses solely due to diarrheal diseases in young animals are estimated in the multi-million dollar range [1]. The most frequent viruses reported include: Coronavirus (i.e., Transmissible Gastroenteritis Virus and Porcine Endemic Diarrhoea Virus), Circovirus Type 2, Rotavirus (RV), Swine Influenza Virus, and Porcine Respiratory and Reproductive Syndrome Virus [2].

Rotavirus is the main cause of viral gastroenteritis in young animals of many species worldwide, and has a raised profile due to its potential communicable nature between humans and animals [1]. Athough all ages of swine are susceptible, it is most commonly seen in young piglets with RV-associated enteritis causative of an estimated 20\% morbidity and 15\% mortality per annum [3] [4]. The virus affects the villus of the small intestine, causing a loss of absorption and osmotic irregularities (including osmotic diarrhea) which lead to malnutrition and malabsorption due to a compromised intestinal epithelial barrier [5] [6]. The Merck Veterinary Manual [7] suggests that nursing pigs often derive antibodies from their mother, with diarrhea occurring anywhere from 5 days to 3 weeks of age or immediately post-weaning. Further, the weaned piglets often become emaciated, stunted, and suffer significant co-morbidities.

Rotavirus is a genus of the family Reoviridae and is a trilaminar viral particle with two double capsid layers surrounding the viral core [8]. There are seven groups (A to G) for rotaviruses based on antigenic specificity with $A$ to $C$ found in human and animal species and D to $G$ only in animals [9]. Four antigenic groups found in swine include A, B, C, and E. There are various G types (i.e., glycoproteins) and P types (protease-sensitive) which tend to segregate according to species-specific patterns [1]. Because of the segmented nature of the RV genome, genetic re-assortment occurs at high frequency which may introduce new human-animal re-assortants, thus impacting on disease spread and vaccination creation [10].

Rotaviruses, generally, and Group A RV, specifically, are causative for the majority of acute viral gastroenteritis in piglets. The most common Group A RV (GARV) is attributed as the pathogen responsible for $90 \%$ of RV gastroenteritis in children and livestock [11] [12]. Group A RV is the leading cause of acute viral diarrhoea in children under 5 years of age claiming nearly half a million children annually with more than half of these deaths in Africa [13]-[15] and a sub-Saharan incidence of more than 300 deaths per 100,000 [14] [16]. Rotavirus strains in Africa are diverse and unusual strains have been reported [17] [18]. Studies respecting the genetic constitution of RV strains in Africa have shown a prevalence of P[6] and G8 genotypes which originate in swine or cows, sheep and other ungulates, respectively [19]-[24].

Rotavirus is environmentally ubiquitous [25], showing a 64\% prevalence in pig manure samples [26] and a high persistence in air, soil and water [27]. In one soil study, enterovirus and rotavirus gRNA were detected in 5\% and $2.5 \%$ of samples, respectively [28]. Additionally, transmission of RV is by fecal-oral route mainly through fecal contaminated animal feeds, water and surfaces. Feces of an infected person or animal contains more than 10 trillion infectious particle per gram, whilst fewer than 100 particles are required in viral transmission [29].

According to the 2012/2013 national statistics [30], there are about 22.8 million cattle, 15.6 million goats, 7.0 million sheep and 2.01 million pigs in Tanzania. There has been a 300\% increase of pig population since 1995, when the estimated population was 434,638 [31]. According to a 2009/2010 report [32], Arusha has a population of 12,289 pigs. In Arusha urban and peri-urban, the rudimentary livestock practices generate close contact and interactions between humans and animals. Additionally, there are questionable conditions potentiating fecal contamination of drinking water due to the settlement schemes and household practices (such as boiling of drinking water).

European, Asian and North American countries have been practicing vaccination to control RV not only in children but also in at risk animals [33]. In Tanzania and East African countries RV animal vaccination is not practiced, but rather there is reliance on passive immunization [25].

Given the global trends in GARV, specifically, and RV, generally, it is important to investigate the patterns within livestock in Tanzania. This study considered the prevalence of GARV in select Arusha peri-urban areas in conjunction with a study of human prevalence within the same areas. This co-terminus approach prompted consideration of potential cross-infection between humans and livestock. Due to the livestock practices related to swine (i.e., close quarters, large litters) and previous studies which suggested ubiquitous RV presence, it was decided to investigate prevalence of RV in a small sample in peri-urban sites of Arusha. 


\section{Material and Methods}

\subsection{Study Area and Population}

This study was conducted in three wards of the Arusha District's peri-urban settings including Lemara, Moshono and Sokoni I. Through a convenience sampling, the project aimed for 100 piglets across the three sites, yielding a total of 110 piglets categorized by age as: sucking (up to 3 weeks; $n=5$ ), weanling ( 3 - 10 weeks; $n=$ 46) and post-weaning/grazing (more than 10 weeks; $n=59$ ).

\subsection{Ethical Approval}

This study was carried out with full approval from the Arusha Regional Livestock Department. Permission to do sampling was granted by farmers from whose farms sampling was done. Sampling was done by qualified and experienced veterinary doctor and personnel from the Regional Livestock Department and the Tanzania Veterinary Laboratory Agency-Arusha (TVLA).

\subsection{Data Collection}

\subsubsection{Demographic Information}

A standardized questionnaire administered to the farmers was used for both diarrhoea and non-diarrhoea piglets to collect information with regard to age category, sex, location, diarrhoea status, recent diarrhoea case on the farm, and type of feeding.

\subsubsection{Faecal Samples}

Faecal samples (one specimen per animal) were collected from animals with and without diarrhoea using aseptic methods (wither rectally using gloved finger or using sterile swabs). Animals without diarrhoea were included because of high incidences of asymptomatic shedding as reported previously [34] [35]. Immediately following collection, samples were placed in labelled sterile plastic tubes and then in cooled boxes on ice for transportation.

\subsection{Extraction of RNA from Faecal Samples}

In order to facilitate RNA extraction, a 10\% fecal suspension in phosphate buffered saline was prepared then spun at $1600(\times \mathrm{g})$ for $5 \mathrm{~min}$ in Eppendorf centrifuge (Eppendorf AG ${ }^{\mathrm{TM}}$, Germany). From this point, RNA extraction was carried out using the Trizol method as previously described by the World Health Organization [36]. The total RNA recovered was suspended in $20 \mu \mathrm{l}$ nuclease free water and stored at $-80^{\circ} \mathrm{C}$ until used for cDNA synthesis.

\subsection{Rotavirus Group A Detection}

Group A Rotavirus (GARV) RNA detection was done using Conventional PCR with a universal primer set NSP3-F with nucleotides 963 to 982 (ACCATCTACACATGACCCTC) and NSP3-R with nucleotides 1049 to 1034 (GGTCACATAACGCCCC) [37] using Thermo Scientific ${ }^{\mathrm{TM}}$ reagents per manufacturer instructions. Prior to this detection, cDNA synthesis was achieved with the Maxima H Minus First Strand cDNA Synthesis TM kit in accordance with the manufacturer's directions (Thermo Scientific ${ }^{\mathrm{TM}}$, Denmark). The Conventional PCR was conducted as follows: Preheating at $94^{\circ} \mathrm{C}$ for 3 minutes for initial denaturation, followed by 40 PCR cycles at $94^{\circ} \mathrm{C}$ for 30 seconds, $56^{\circ} \mathrm{C}$ for 30 seconds and $72^{\circ} \mathrm{C}$ for 1 minute and a final extension at $72^{\circ} \mathrm{C}$ for 10 minutes. Prior to removal from the C1000 Touch $^{\mathrm{TM}}$ Thermo Cycler (Bio-Rad Laboratories Inc, USA), samples were held at $4^{\circ} \mathrm{C}$. The PCR products from the reaction above were analysed in $5 \%$ agarose (Sigma, Type-1A, Madrid, Spain) gel (stained with GelGreen ${ }^{\mathrm{TM}}$ (Thermo Scientific, Denmark) and transilluminated and imaged in a BioRad Gel Doc ${ }^{\mathrm{TM}}$ EZ Imager (Bio-Rad Laboratories Inc, USA). An Ultra-Low Range (ULR) nucleic ladder was used and gel electrophoresis ran for one hour with 100 voltage.

\subsection{Data Analysis}

Data analysis was done using the Statistical Package for Social Sciences (SPSS Version 20). Using this software, 
Fisher's Exact Test was done for testing statistical associations between Rotavirus positivity and select risk factors. A p value $<0.05$ was considered statistically significant.

\section{Results}

Samples were collected in July 2014 from three areas of Arusha peri urban; Lemara ( $n=40)$, Moshono $(n=34)$ and Sokoni I $(\mathrm{n}=36)$. Out of the 110 samples tested, $46(41.8 \%)$ were positive for Rotavirus. The demographic description of the piglets' sample group and Rotavirus status is shown in Table 1.

In considering contagiousness, we observed approximately $1 / 3^{\text {rd }}$ of piglets were located in environments where there were recent diarrheal cases. The study showed a significant association between a recent case of diarrhoea in the farm and Rotavirus status $\mathrm{p}<0.05(\mathrm{p}=0.038)$.

Although there was no significance in RV to gender $(\mathrm{p}=0.19)$, the age of the source was significant $(\mathrm{p}=$ 0.013). From a descriptive level, we noted that the small sample of suckling piglets showed high RV prevalence. This finding requires further exploration and replication.

The study findings indicated a significance based on location $(\mathrm{p}=0.0037)$. Again at the descriptive statistical level, we noted that one site had a greater than $50 \%$ incidence of RV in the sample. Again, this requires further exploration and replication.

\section{Discussion}

Rotaviruses are detrimental pathogens in animals worldwide causing gastroenteritis that affects young animals of many species [38] [39]. In pigs, Rotavirus associated enteritis is a major problem in pre-weaning, weaning and post weaning piglets [40]. There have limited studies in Tanzania on prevalence in livestock species.

In this study, non-diarrheic piglets showed RV positive status $40.5 \%$ of cases $(n=32)$. This finding is consistent with previously reported asymptomatic shedding of RV by non-diarrheic pigs [41], which poses risk of spreading the disease in the farm and, dependent upon strain, to those living within close contact (especially children).

\section{Table 1. Description of piglet sample and Rotavirus status.}

\begin{tabular}{|c|c|c|}
\hline Parameter & Number of samples & Rotavirus prevalence (\%) \\
\hline \multicolumn{3}{|l|}{ Location } \\
\hline Lemara & 40 & $13(32.5 \%)$ \\
\hline Moshono & 34 & 19 (55.9\%) \\
\hline Sokoni I & 36 & $14(38.9 \%)$ \\
\hline \multicolumn{3}{|l|}{ Diarrhoea status } \\
\hline With diarrhoea & 31 & $14(45.2 \%)$ \\
\hline Without diarrhoea recent diarrhoea on farm & 79 & $32(40.5 \%)$ \\
\hline Recent case & 35 & $20(57.1 \%)$ \\
\hline No case & 75 & $26(34.7 \%)$ \\
\hline \multicolumn{3}{|l|}{ Sex } \\
\hline Male & 39 & $19(47.8 \%)$ \\
\hline Female & 71 & 27 (38.0\%) \\
\hline \multicolumn{3}{|l|}{ Age category/feeding type } \\
\hline$<3$ weeks/suckling & 5 & $4 \quad(80 \%)$ \\
\hline 3 - 10 weeks/weaning & 46 & $19(41.3 \%)$ \\
\hline >10 weeks/grazing/fattening & 59 & $23(39 \%)$ \\
\hline
\end{tabular}


The prevalence of GARVs, in this study, at $41.8 \%$ is comparable with previously reported studies [42]-[50] ranging from $17 \%$ to $67.3 \%$. The high prevalence and significant variability justifies the need of a strategy to roll out a program for vaccinating pigs against RV and training extension workers on disease control programs in Tanzania.

Rotaviruses cannot replicate outside a host's cell, but there is evidence they can persist in the environment and ground water for several months [51]-[54]. This persitance provides an opportunity for the viral particles to potentially be transmitted to naïve animals through contaminated water, surfaces, and feeds in a setting where pigs are enclosed in one area with improper hygiene and sanitation. A recent study showed that human bacteroidales, pathogenic E. coli, and rotavirus genes were detectable in soil samples, which highlights the need for attention on this potential transmission pathway in low income countries [55]. Our significant findings on recent diarrheal events and locational variance would align with these observations. It is recognized that there is a need to further study how the environment contributes to exposure routes for RV related diarrhoea in pig populations in Tanzania.

It is noted that the African Rotavirus Surveillance Network (AFR RSN) was established in 1998 as a regional partnership between African countries, the World Health Organization (WHO) and its partners [56]. This network has a critical role in tracking, creating awareness, and building skills in relation to RV disease across the continent. The role of this network should be further highlighted and set the research agenda for RV related diseases.

We refer the reader to a recent publication on RV infections in children from the same location (Gachanja et al., 2014) which calls for further studies to fully characterise the circulating RV genotypes across species in view of the public health implications.

\section{Conclusion}

This study has affirmed previous study findings of the prevalence of Group A Rotavirus within porcine populations in select peri-urban communities in northern Tanzania. These findings highlight the critical need to create awareness and programs (i.e., vaccination programs) for these populations for economic and social well-being.

\section{Acknowledgements}

This work was jointly financed by the Nelson Mandela African Institution of Science and Technology students' scholarship and the Canadian Department of Foreign Affairs, Trade and Development (DFATD) through the Mama Kwanza Socio-economic Health Initiative, without any direct involvement of the funders in the project design or dissemination. We appreciate the farmers who took part in this study for their consent and cooperation. We are grateful to Dr. Joshua Amimo, Dr. Apollinare Djikeng and BecA ILRI hub for the training and assistance in designing our protocol. We acknowledge the support and cooperation of Dr. Mandike and Mr. Emmanuel Mbise from the Arusha Regional Livestock Department and the Tanzania Veterinary Laboratory AgencyArusha (TVLA). We greatly appreciate the assistance and support of Dr. Haikael Martin in data organization and analysis.

\section{Competing Interests}

The authors have declared that no competing interests exist.

\section{Authors' Contributions}

Author A co-designed and conducted the research, managed the data, co-analyzed the data and drafted an early version of this paper. Author B co-designed and facilitated the research, reviewed all analysis of the data, as the co-supervisor of this project. Author $\mathrm{C}$ facilitated all aspects of the research, co-supervised this project, and re-drafted this paper. All authors reviewed the most recent version of the submission and approved.

\section{References}

[1] Martella, V., Bányai, K., Matthijnssens, J., Buonavoglia, C. and Ciarlet, M. (2010) Zoonotic Aspects of Rotaviruses. Veterinary Microbiology, 140, 246-255. http://dx.doi.org/10.1016/j.vetmic.2009.08.028 
[2] Aminu, J.O., Vlasova, A. and Saif, L. (2013) Detection and Genetic Diversity of Porcine Group A Rotaviruses in Historic (2004) and Recent (2011/12) Swine Fecal Samples in Ohio, USA: Predominance of G9P[13] Genotype in Nursing Piglets. Journal of Clinical Microbiology, 3, 193-212.

[3] Dewey, C., Carman, S., Pasman, T., Josephson, G. and McEwen, B. (2003) Relationship between Group A Porcine Rotavirus and Management Practices in Swine Herds in Ontario. Canadian Veterinary Journal, 44, 649-653.

[4] Paul, P. and Stevenson, G. (1992) Rotavirus and Reovirus. In: Leman, A.D., Straw, B.E., Mengeling, W.L., D’Ailaire, S. and Taylor, D., Eds., Diseases of Swine, 7th Edition, Iowa State University Press, Ames.

[5] Zijlstra, R.T., Donovan, S.M., Odle, J., Gelberg, H.B., Petschow, B.W. and Gaskins, H.R. (1997) Protein-Energy Malnutrition Delays Small-Intestinal Recovery in Neonatal Pigs Infected with Rotavirus. Journal of Nutrition, 127, 11181127. PMID: 9187626.

[6] Ciarlet, M. and Estes, M.K. (2001) Interactions between Rotavirus and Gastrointestinal Cells. Current Opinion in Microbiology, 4, 435-441. http://dx.doi.org/10.1016/S1369-5274(00)00232-0

[7] Merck Veterinary Manual (2013) Rotaviral Enteritis in Pigs. http://www.merckvetmanual.com/mvm/digestive_system/intestinal_diseases_in_pigs/rotaviral_enteritis_in_pigs.html

[8] Gentsch, J.R., Laird, A.R., Bielfelt, B., et al. (2005) Serotype Diversity and Reassortment between Human and Animal Rotavirus Strains: Implications for Rotavirus Vaccine Programs. International Journal of Infectious Diseases, 192, S146-S159. http://dx.doi.org/10.1086/431499

[9] Santos, N. and Hoshino, Y. (2005) Global Distribution of Rotavirus Serotypes/Genotypes and Its Implication for the Development and Implementation of an Effective Rotavirus Vaccine. Reviews in Medical Virology, 15, 29-56. http://dx.doi.org/10.1002/rmv.448

[10] Matthijnssens, J., Rahman, M., Yang, X., Delbeke, T., Arijs, I., Kabue, J.-P., Muyembe, J.-J.T. and Van Ranst, M. (2006) G8 Rotavirus Strains Isolated in the Democratic Republic of Congo belong to the DS-1-Like Genogroup. Journal of Clinical Microbiology, 44, 1801-1809. http://dx.doi.org/10.1128/JCM.44.5.1801-1809.2006

[11] Cook, N., Bridger, J., Kendall, K., Iturriza Gomora, M., El-Attar, L. and Gray, J. (2004) The Zoonotic Potential of Rotavirus. Journal of Infection, 48, 289-302. http://dx.doi.org/10.1016/j.jinf.2004.01.018

[12] Midgley, S.E., Banyai, K., Buesa, J., Halaihel, N., Hjulsager, C.K., et al. (2012) Diversity and Zoonotic Potential of Rotaviruses in Swine and Cattle across Europe. Veterinary Microbiology, 156, 238-245. http://dx.doi.org/10.1016/j.vetmic.2011.10.027

[13] Liu, L., Johnson, H.L., Cousens, S., et al. (2012) Global, Regional, and National Causes of Child Mortality: An Updated Systematic Analysis for 2010 with Time Trends since 2000. The Lancet, 379, 2151-2161. http://dx.doi.org/10.1016/S0140-6736(12)60560-1

[14] Tate, J.E., Burton, A.H., Boschi-Pinto, C., et al. (2008) Estimate of Worldwide Rotavirus Associated Mortality in Children Younger Than 5 Years before the Introduction of Universal Rotavirus Vaccination Programmes: A Systematic Review and Meta-Analysis. Lancet Infectious Diseases, 12, 136-141. http://dx.doi.org/10.1016/S1473-3099(11)70253-5

[15] World Health Organization (2008) Rotavirus Deaths, under 5 Years of Age, as of 31 January 2012. www.who.int/entity/immunization/monitoring_surveillance/burden/estimates/rotavirus/ChildRota2008.xls?ua=l

[16] Tanzanian Population Census.

[17] Sanchez-Padilla, E., Grais, F.R., Guerin, P.J., et al. (2009) Burden of Disease and Circulating Serotypes of Rotavirus Infection in Sub-Saharan Africa: Systematic Review and Meta-Analysis. Lancet Infectious Diseases, 9, 567-576. http://dx.doi.org/10.1016/S1473-3099(09)70179-3

[18] Todd, S., Page, N.A., Steele, A., et al. (2010) Rotavirus Strain Types Circulating in Africa: Review of Studies Published during 1997-2006. Journal of Infectious Diseases, 202, S34-S42. http://dx.doi.org/10.1086/653555

[19] Seheri, M., Nemarude, L., Peenze, I., Netshifhefhe, L., Nyaga, M.M., et al. (2014) Update of Rotavirus Strains Circulating in Africa from 2007 through 2011. Pediatric Infectious Disease Journal, 33, S76-S84. http://dx.doi.org/10.1097/inf.0000000000000053

[20] Jere, K.C., Mlera, L., O’Neill, H.G., Peenze, I. and van Dijk, A.A. (2012) Whole Genome Sequence Analyses of Three African Bovine Rotaviruses Reveal That They Emerged through Multiple Reassortment Events between Rotaviruses from Different Mammalian Species. Veterinary Microbiology, 159, 245-250. http://dx.doi.org/10.1016/j.vetmic.2012.03.040

[21] Matthijnssens, J., Potgieter, C.A., Ciarlet, M., Parreno, V., Martella, V., et al. (2009) Are Human P[14] Rotavirus Strains the Result of Interspecies Transmissions from Sheep or Other Ungulates That Belong to the Mammalian Order Artiodactyla? Journal of Virology, 83, 2917-2929. http://dx.doi.org/10.1128/JVI.02246-08

[22] Cunliffe, N.A., Gentsch, J.R., Kirkwood, C.D., Gondwe, J.S., Dove, W., et al. (2000) Molecular and Serologic Char- 
acterization of Novel Serotype G8 Human Rotavirus Strains Detected in Blantyre, Malawi. Virology, 274, 309-320. http://dx.doi.org/10.1006/viro.2000.0456

[23] Papp, H., Laszlo, B., Jakab, F., Ganesh, B., De Grazia, S., et al. (2013) Review of Group A Rotavirus Strains Reported in Swine and Cattle. Veterinary Microbiology, 165, 190-199. http://dx.doi.org/10.1016/j.vetmic.2013.03.020

[24] Martella, V., Banyai, K., Ciarlet, M., Iturriza-Gomara, M., Lorusso, E., et al. (2006) Relationships among Porcine and Human P[6] Rotaviruses: Evidence That the Different Human P[6] Lineages Have Originated from Multiple Interspecies Transmission Events. Virology, 344, 509-519. http://dx.doi.org/10.1016/j.virol.2005.08.029

[25] Yuan, L., Stevenson, G.W. and Saif, L.J. (2006) Rotavirus and Reovirus. In: Straw, B.E., Zimmerman, J.J., D’Allaire, S. and Taylor, D.J., Eds., Diseases of Swine, Blackwell Publishing, Iowa, 435-454.

[26] Costantini, V.P., Azevedo, A.C., Li, X., Williams, M.C., Michel, F.C. and Saif, L.J. (2007) Effects of Different Animal Waste Treatment Technologies on Detection and Viability of Porcine Enteric Viruses. Applied and Environmental Microbiology, 73, 5284-5291. http://dx.doi.org/10.1128/AEM.00553-07

[27] Ziemer, C.J., Bonner, J.M., Cole, D., Vinje, J., Constantini, V., Goyal, S., Gramer, M., Mackie, R., Meng, X.J., Myers, G. and Saif, L.J. (2010) Fate and Transport of Zoonotic, Bacterial, Viral, and Parasitic Pathogens during Swine Manure Treatment, Storage, and Land Application. Journal of Animal Science, 88, E84-E94. http://dx.doi.org/10.2527/jas.2009-2331

[28] Pickering, A.J., Julian, T.R., Marks, S.J., Mattioli, M.C., Boehm, A.B., Schwab, K.J. and Davis, J. (2010) Fecal Contamination and Diarrheal Pathogens on Surfaces and in Soils among Tanzanian Households with and without Improved Sanitation. Environmental Science \& Technology, 46, 5736-5743.

[29] Ansari, S., Sherchand, J., Rijal, B.P., Parajuli, K., Mishra, S.K., Dahal, R.K., Shrestha, S.,Tandukar, S., Chaudhary, R., Kattel, H.P., Basnet, A. and Pokhrel, B.M. (2013) Characterization of Rotavirus Causing Acute Diarrhoea in Children in Kathmandu, Nepal, Showing the Dominance of Serotype G12. Journal of Microbiology, 62, 114-120.

[30] URT (2012) National Sample Census of Agriculture 2007/2008 Small Holder Agriculture Volume III: Livestock Sector-National Report. Unpublished, Prime Minister's Office, Dar es Salaam.

[31] Wilson, R. and Swai, E. (2014) Pig Production in Tanzania: A Critical Review. Tropicultura, 32, 46-53.

[32] URT (2010) Livestock Sector Development Strategy. Unpublished, Ministry of Livestock and Fisheries Development, Dar es Salaam.

[33] Bernstein, D.I. (2009) Rotavirus Overview. Pediatric Infectious Disease Journal, 28, S50-S53. http://dx.doi.org/10.1097/INF.0b013e3181967bee

[34] Steyer, A., Poljasak-Prijatelj, M., Barlic-Maganja, D. and Marin, J. (2008) Human, Porcine and Bovine Rotaviruses in Slovenia: Evidence of Interspecies Transmission and Genome Reassortment. Journal of General Virology, 89, 16901698. http://dx.doi.org/10.1099/vir.0.2008/001206-0

[35] Nataraju, S., Chattopadhyay, U. and Krishnan, T. (2009) A Study on the Possibility of Zoonotic Infection in Rotaviral Diarrhoea among Calves and Buffalo Calves in and around Kolkata, India. European Review for Medical and Pharmacological Sciences, 13, 7-11.

[36] World Health Organization. Manual of Rotavirus Detection and Characterization Methods. World Health Organization, Geneva.

[37] Pang, X.L., Lee, B., Boroumand, N., Leblanc, B., Preiksaitis, J.K. and Ip, C.C.Y. (2004) Increased Detection of Rotavirus Using a Real Time Reverse Transcription-Polymerase Chain Reaction (RT-PCR) Assay in Stool Specimens from Children with Diarrhea. Journal of Medical Virology, 72, 496-501. http://dx.doi.org/10.1002/jmv.20009

[38] Parashar, U.D., Hummelman, E.G., Bresee, J.S., Miller, M.A. and Glass, R.I. (2003) Global Illness and Deaths Caused by Rotavirus Disease in Children. Emerging Infectious Disease, 9, 565-572. http://dx.doi.org/10.3201/eid0905.020562

[39] Tamerhiro, C.Y., Alfieri, A.F., Medici, C. and Alfieri, A.A. (2003) Segmented Double-Stranded Genomic RNA Viruses in Fecal Samples from Broiler Chicken. Brazilian Journal of Microbiology, 34, 344-348. http://dx.doi.org/10.1590/S1517-83822003000400013

[40] Kapikian, A. (1996) Overview of Viral Gastroenteritis. Springer, Vienna. http://dx.doi.org/10.1007/978-3-7091-6553-9_2

[41] Lecce, J.G. and King, M.W. (1978) Role of Rotavirus (Reo-Like) in Weanling Diarrhea of Pigs. Journal of Clinical Microbiology, 8, 454-458.

[42] Kim, H.J., Park, S.I., Ha, T.P.M., Jeong, Y.J., Kim, H.H., Kwon, H.J., Kang, M.I., Cho, K.O. and Park, S.J. (2010) Detection and Genotyping of Korean Porcine Rotaviruses. Veterinary Microbiology, 144, 274-286. http://dx.doi.org/10.1016/j.vetmic.2010.01.019

[43] Racz, M.L., Kroeff, S.S., Munford, V., Caruzo, T.A., Durigon, E.L., Hayashi, Y., Gouvea, V. and Palombo, E.A. (2000) Molecular Characterization of Porcine Rotaviruses from the Southern Region of Brazil: Characterization of an Atypical 
Genotype G[9] Strain. Journal of Clinical Microbiology, 38, 2443-2446.

[44] Kusumakar, A.L., Malik, Y.S. and Prasad, G. (2010) Genomic Diversity among Group A Rotaviruses from Diarrheic Children, Piglets, Buffalo and Cow Calves of Madhya Pradesh. Indian Journal of Microbiology, 50, 83-88. http://dx.doi.org/10.1007/s12088-010-0016-y

[45] Halaihel, N., Masia, R., Fernandez-Jimenez, M., Ribes, J., Montava, R., De Blas, I., Girones, O., Alonso, J. and Buesa, J. (2010) Enteric Calicivirus and Rotavirus Infections in Domestic Pigs. Epidemiology \& Infection, 138, 542-548. http://dx.doi.org/10.1017/S0950268809990872

[46] Katsuda, K., Kohmoto, M., Kawashima, K. and Tsunemitsu, H. (2006) Frequency of Enteropathogen Detection in Suckling and Weaned Pigs with Diarrhea in Japan. Journal of Veterinary Diagnostic Investigation, 18, 350-354. http://dx.doi.org/10.1177/104063870601800405

[47] Marthaler, D., Rossow, K., Gramer, M., Collins, J., Goyal, S., Tsunemitsu, H., Kuga, K., Suzuki, T., Ciarlet, M. and Matthijnssens, J. (2012) Detection of Substantial Porcine Group B Rotavirus Genetic Diversity in the United States, Resulting in a Modified Classification Proposal for G Genotypes. Virology, 433, 85-96. http://dx.doi.org/10.1016/j.virol.2012.07.006

[48] Lamhoujeb, S., Cook, A., Pollari, F., Bidawid, S., Farber, J. and Mattison, K. (2010) Rotaviruses from Canadian Farm Samples. Archives of Virology, 155, 1127-1137. http://dx.doi.org/10.1007/s00705-010-0700-6

[49] Khamrin, P., Maneekarn, N., Peeraome, S., Chan-It, W., Yagyu, F., Okitsu, S. and Ushijima, H. (2007) Novel Porcine Rotavirus of Genotype P[27] Shares New Phylogenetic Lineage with G2 Porcine Rotavirus Strain. Virology, 361, 243252. http://dx.doi.org/10.1016/j.virol.2006.12.004

[50] Tonietti, P.O., Hora, A.S., Silva, F.D., Ruiz, V.L. and Gregori, F. (2013) Phylogenetic Analysis of the VP4 and VP7 Genes of Porcine Group A Rotaviruses in Sao Paulo State, Brazil: First Identification of G5P[23] in Piglets. Journal of Clinical Microbiology, 51, 2750-2753. http://dx.doi.org/10.1128/JCM.01175-13

[51] D’Arcy, N., Cloutman-Green, E., Klein, N. and Spratt, D.A. (2014) Environmental Viral Contamination in a Pediatric Hospital Outpatient Waiting Area: Implications for Infection Control. American Journal of Infection Control, 42, 856860. http://dx.doi.org/10.1016/j.ajic.2014.04.014

[52] Ramos, A.P.D., Stefanelli, C.C., Linhares, R.E.C., Brito, B.G.D. and Nozawa, C.M. (1998) The Infectivity of Pig Rotavirus in Stools. Brazilian Journal of Veterinary Research and Animal Science, 35, 84-87. http://dx.doi.org/10.1590/S1413-95961998000200007

[53] Saif, L., Rosen, B. and Parwani, A. (1994) Animal Rotaviruses. In: Kapikan, A.Z., Ed., Viral Infect Gastrointestinal Tract, 2nd Edition, Marcel Dekker, New York.

[54] Hrdy, D.B. (1987) Epidemiology of Rotaviral Infections in Adults. Reviews of Infectious Diseases, 9, 461-469. http://dx.doi.org/10.1093/clinids/9.3.461

[55] Mattioli, M.C., Pickering, A.J., Gilsdorf, R.J., Davis, J. and Boehm, A.B. (2013) Hands and Water as Vectors of Diarrhea! Pathogens in Bagamoyo, Tanzania. Environmental Science \& Technology, 47, 355-363. http://dx.doi.org/10.1021/es303878d

[56] Gachanja, E., Buza, J. and Petrucka, P. Molecular Detection of Group A Rotavirus in Children under Five in Urban and Peri-Urban Arusha, Tanzania. (Submitted and in Process) 